\title{
Lachish River event monitored for toxicity using bioluminescent reporter organisms
}

\author{
Erel Lior ${ }^{1}$, Tim Axelrod ${ }^{1}$, Evgeni Eltzov ${ }^{2}$, Ariel Kushmaro ${ }^{1,3,4}$ and Robert S. Marks ${ }^{1,3,4 *}$
}

\begin{abstract}
The Lachish River has suffered from recurring pollution incidents for the past decade. On October $11^{\text {th }}, 2017$, another contamination in the river was sighted, as thousands of dead fish were found floating. Samples from the river were retrieved and tested through a whole cell bioluminescent bacterial bioreporter system as well as conventional analytical methods, and the results from both methods were analyzed and compared, even though initially these two collecting events were not coordinated. The information acquired from the whole cell reporter was consistent with that obtained from conventional methods. Both approaches indicated a large concentration of microorganisms as deduced from K802NR E. coli strain reaction and coliforms count. The high water conductivity measured in collected samples were closer downstream, and attributed to the diffusion of salts from the Mediterranean Sea which affected bacterial viability as seen from the decreased reaction of E. coli strains TV1061 and DPD2794. In addition, the bacterial indicators' kinetic patterns have shown indication for the presence of a genotoxic substance from only one of the collection sites, which was tested positive for the herbicide Metazachlor, itself known to have genotoxic effects. The correlation between both approaches, along with the biosensor's ability to assess biological influences, suggests that the whole cell bioluminescent bacterial bioreporter bioassay as an easy, simple and efficient approach for water toxicity monitoring.
\end{abstract}

Keywords: water pollution, toxicity, bacteria, bioluminescence, biosensor, bioreporter, Lachish, Lakhish

${ }^{1}$ Avram and Stella Goldstein-Goren Department of Biotechnology Engineering, Ben-Gurion University of the Negev, P.O. Box 653, Be'er Sheva 8410501, Israel;

2Department of Postharvest Science of Fresh Produce, Agricultural Research Organization, Rishon Letsion; 750501, Israel.

${ }^{3}$ National Institute of Biotechnology in the Negev, Ben-Gurion University of the $\mathrm{Ne}$ gev, Beer-Sheva, Israel

${ }^{4}$ The Ilse Katz Center for Meso and Nanoscale Science and Technology, Ben-Gurion University of the Negev, Beer-Sheva, Israel

*Corresponding author: R. S. Marks E-mail: rsmarks@bgu.ac.il

DOI: 10.2478/ebtj-2018-0008

\section{Introduction}

The Lachish River, once an ancient mooring point for traders, is a 70-Kilometer seasonal stream, with a drainage basin of about 1000 square kilometers, that flows to the Mediterranean Sea through the north part of Ashdod city, Israel (1). It crosses the Ashdod industrial area, making it vulnerable to various contaminants. The river is the natural habitat of an assortment of flora and fauna, including fish and birds, as well as endangered winter thorn trees growing at the river banks (2). Back in the 1960s the Lachish River was a perennial stream with potable water, that was safe for both swimming and fishing. However, with growing population along the course of the river, and a lack of proper sewage facilities, by either municipalities or factories, the stream has become polluted and is considered hazardous (1), this until 1991, when an intensive restoration project, under the supervision of the "Ashdod-Yavne cities association for environmental quality control", was initiated, and in 1996 the Lachish-Ashdod Park was inaugurated (3). Since 2009, at least five cases of pollution occurred in the river, which were attributed to industrial facilities, sewage, and unknown origins $(4,5)$. In August 2009, the river was contaminated due to a fire in the "Adama Agan Chemicals" industrial plant. Traces of herbicides and BOD levels 3.5 times higher than the accepted normal were found in the river waters (6). Two years later, in July 2011, the river was contaminated again as a result of sewage malfunctions, causing coliform concentration in the river to be significantly high. In response, the city of Ashdod constructed the "Bezeq drainage" in order to prevent sewage leakages into the 
river (4). Another leakage occurred in August 2013, and many birds covered in oil were discovered near the river. The black fluid, thought to be Mazut, was pumped out of the river and the damaged pipe was repaired (4). In June 2014, the department of health approved recreational sailing along the river, after the authorities decided that the water quality was met the required safety regulations (7), however in September 2015 the city's main sewage pipe collapsed and the sewage entered the river, causing up until early 2017 millions of shekels to be spent on cleaning the river (4). In the beginning of the year 2017, the river was declared one of the three least polluted rivers in Israel (8). Less than a year later, around October 2017, the river was polluted once more; thousands of fish were killed, and the barrier separating the river from the Mediterranean Sea was opened in order to dilute the contamination and save the remaining fish (9). The pollutants probably originated from various sources such as groundwater pollution, convection of agrochemicals, accidental spillage and discharge of untreated waste (10).

The river is being monitored for coliform concentration weekly by the Ashdod-Yavne regional association for environmental protection. If any cause for alarm does occur, the association tests the contaminated water using conventional analytical approaches. Examples of these techniques are total organic carbon (TOC), biological oxygen demand (BOD), chemical oxygen demand (COD), TSS and coliforms. In addition to that, gas chromatography (GC), inductively-coupled plasma mass spectrometry (ICP-MS) and high-performance liquid chromatography (HPLC), which are all very sensitive and allow for a precise determination of any chemicals in water sources. However, such approaches do present several disadvantages; they are time consuming (days to weeks), expensive, and may detect a small or restricted group of compounds at any given time. Furthermore, the biological effect of the contaminant cannot be assessed or measured by these conventional methods (11)(13). Thus, when a river exhibits dead floating fish on its surface with an obvious toxicity effect, it would be useful to search for such a phenomenon. It would therefore be important to include as first alarm monitoring a biologically based toxicity bioassay so as to identify and assess putative biological hazards, whose actual causative agents, if any, may then later be assessed for their presence in the sample. Whole cell based bioreporter bioassays offer advantages as they are sensitive, provide a rapid measurement, are cost effective, and they provide an indication of the type of biological effect caused by the causative substances or other environmental stresses (14). These sensors do not require any complex sample pretreatment nor any substrate addition for signal generation (15). Previous studies have shown that these whole cell based 'biosensors' have sufficient sensitivity in detecting different toxicants and have successfully detected toxicity in environmental samples $(14,16)$, including those from the Lachish river after continual pollution events.

Our present study report is a case study of a pollution event detected in the Lachish River (October 1 $\left.1^{\text {th }}, 2017\right)$. The source of the pollution, causing the death of thousands of fish and other sea life, is still undetermined. Herein we attempted to ana- lyze the toxicity potential of the water samples resulting from the reported pollution event, and suggest a possible source of contamination. Bioluminescent genetically engineered bioreporter bacteria were used as indicators for various factors, in testing several water samples along the river. The results were validated with conventional methods.

\section{Materials and Methods \\ Materials}

Luria-Bertani (LB) Broth Difco (244629), Miller (10 gr. tryptone, 5 gr. yeast extract and 10 gr. sodium chloride per liter) and LB agar Difco (244520) were purchased from Becton Dickinson (USA). Kanamycin sulfate (K1377-5G), Mitomycin C (M0503), Nalidixic acid (N8878-5G), and Ampicillin (A9518-5G) were purchased from Sigma. Ethanol (19-009101-80) was purchased from Romical. Phenol (16016) was purchased from Riedel-de Haen. Most stock solutions were diluted with double distilled water (DDW), and nalidixic acid was diluted with acetonitrile.

\section{Bacterial strains}

Five different Escherichia coli strains were used in the study (DPD2794, TV1061, DPD2544 and DPD1718 were obtained as a gift from S. Belkin (Hebrew University, Jerusalem, Israel), while K802NR, was obtained from J. Davies (University of Calgary, Calgary, Canada)). Each strain harbors a plasmid-borne fusion of the specific promoters to a reporter gene (Table 1). The recA promoter in strains DPD2794 and DPD1718 activates a DNA repair system due to DNA damage (17). The heat-shock grpE promoter in strain TV1061 is sensitive to metabolic changes, such as with cytotoxic substances (18). K802NR carries the pSB1075 infused with lasRI and luxCDABE and contains the lasI quorum sensing promoter. Quorum sensing is the regulation of gene expression, as a result of changes in microbial population density. The bacteria produce and release different chemical signaling molecules. When their concentration increases so does that of the signaling molecules, and these are then detected by fellow bacteria. These molecules affect gene expression, thus modifying bacterial activities, such as antibiotic production, motility, biofilm formation and mortality $(15,19)$. The fabA promoter in strain DPD2544 is induced when fatty acid biosynthesis pathways are interrupted (20). All these promoters are plasmid-integrated to the lux CDABE reporter operon, which has five promotorless structural genes. These are responsible for both the heterodimeric luciferase units (lux A and B) and the synthesis of the luciferase substrate, tetradecanal, by an ATP and NADPH-dependent multi-enzyme complex, composed of fatty acid reductase, transferase, and a synthetase (lux C, D and E) (21). Strain stocks were stored at $-80^{\circ} \mathrm{C}$ with $20 \%(\mathrm{v} / \mathrm{v})$ of glycerol as a cell cryoprotectant additive (22). When needed, the bioreporter strains were taken from the stock solution and placed on LB-agar plates $(\mathrm{NaCl} 5 \mathrm{~g} \mathrm{~L}-1$, yeast extract $5 \mathrm{~g} \mathrm{~L}-1$, tryptone $10 \mathrm{~g} \mathrm{~L}-1$, agar $15 \mathrm{~g} \mathrm{~L}-1)$ supplemented with $50 \mu \mathrm{g} / \mathrm{mL}$ kanamycin for DPD1718, or $100 \mu \mathrm{g} / \mathrm{mL}$ ampicillin for the remaining strains. After growth overnight at $37^{\circ} \mathrm{C}$, the culture plates were stored at $4^{\circ} \mathrm{C}$ for use in future experiments. 
Table 1. List of the bioluminescence bacteria

\begin{tabular}{|c|c|c|c|c|c|c|}
\hline $\begin{array}{c}\text { Strain } \\
\text { designation }\end{array}$ & $\begin{array}{l}\text { E. coli host } \\
\text { strain }\end{array}$ & Promoter & $\begin{array}{c}\text { Stress } \\
\text { sensitivity }\end{array}$ & $\begin{array}{l}\text { Inducer used in } \\
\text { this study }\end{array}$ & Concentration & Reference \\
\hline K802NR & Psb1075 & lasl & Nalidixc acid (gorA) & Nalidixic acid & $100 \mathrm{mg} / \mathrm{L}$ & (23) \\
\hline TV1061 & RFM443 & grpE & $\begin{array}{c}\text { Heat shock } \\
\text { (general stress) }\end{array}$ & Ethanol & $0.43 \mathrm{M}$ & (24) \\
\hline DPD2794 & RFM443 & recA & $\begin{array}{c}\text { SOS } \\
\text { (genotoxicity) }\end{array}$ & Mitomycin C & $8000 \mathrm{ppb}$ & (25) \\
\hline DPD2544 & W3110 & fabA & $\begin{array}{l}\text { Fatty acid availabilty } \\
\text { (general stress) }\end{array}$ & Phenol & $5.2 \times 10^{-4} \mathrm{M}$ & (20) \\
\hline DPD1718 & DPD1692 & recA & $\begin{array}{c}\text { SOS } \\
\text { (genotoxicity) }\end{array}$ & Mitomycin C & $8000 \mathrm{ppb}$ & (26) \\
\hline
\end{tabular}

\section{Growth conditions}

Bacterial cultivation prior to measurements was performed in $10 \mathrm{~mL} \mathrm{LB}$-medium $(\mathrm{NaCl} 5 \mathrm{~g} \times \mathrm{L}-1$, yeast extract $5 \mathrm{~g} \times \mathrm{L}-1$, tryptone $10 \mathrm{~g} \times \mathrm{L}-1)(27)$, supplemented with $50 \mu \mathrm{g} / \mathrm{mL}$ kanamycin for DPD1718, or $100 \mu \mathrm{g} / \mathrm{mL}$ ampicillin for the remaining strains. Cells were grown overnight at $37{ }^{\circ} \mathrm{C}$ in a rotary thermo-shaker (MaxQ 4450, ThermoScientific, USA) at $150 \mathrm{rpm}$ in the presence of the appropriate antibiotic. Cultures were then diluted to approximately $107 \mathrm{cells} / \mathrm{mL}$ and re-grown in $10 \mathrm{~mL} \mathrm{LB}$ at $30^{\circ} \mathrm{C}$ without shaking and without antibiotics, until an early exponential phase (OD600 of 0.2) as determined by an Ultrospec 2100 Pro spectrophotometer (Amersham, England).

\section{Environmental water collection}

Two days after the event whereby thousands of fish were sighted floating on the riverbank, six samples (Fig. 1) were collected and tested through a whole cell bioluminescent bacteria reporter bioassay system: point a, located close to the estuary $(31.816031,34.643630)$, point $b$, located under the ort bridge $(31.816968,34.646418)$, point $c$, located close to the Lachish theme park (31.818870, 34.6529220, Fig. 4). Point d was located under the Herzl Bridge (31.822785, 34.659699), at the site, pelicans were spotted eating the dead fish; point e was in the relative vicinity of the Lachish farm and other industrial facilities $(31.824513,34.668117)$, where a large number of dead fish and oily stains were detected; and point f, near the Metapic drain (31.826405, 34.670759, Fig. 4), this drain gathers all the north factories waste. All samples were collected into $50 \mathrm{~mL}$ tubes (REF 227270, Greiner) and kept at $4^{\circ} \mathrm{C}$ until tested. An additional eight samples were collected, on the same day of the event, therefore, two days before our aforementioned collection, and tested using conventional methods: point 1, located at the river's estuary; point 2, near the Lachish theme park; points 3-6 were collected in adjacent locations, close to the Herzl Bridge; collection point 7 was located close to the Lachish farm, while point 8 was near the Metapic drain (Fig. 1).

\section{Bioluminescence assay}

Bioluminescent activity was measured using a Luminoskan Ascent luminometer (Thermo Fisher Scientific, United States). The measurement procedure took place in white opaque 96well microtiter plates (Dynatech) containing $90 \mu \mathrm{L}$ of the bacterial culture at OD490 and $10 \mu \mathrm{L}$ of the various collected river water samples. Two additional wells served as negative and positive controls, containing $90 \mu \mathrm{l}$ bacteria and $10 \mu \mathrm{l}$ control (for all strains, DDW served as negative control). Ethanol 4\%(v/v) served as a positive control for TV1061 (28), mitomycin C at $8000 \mathrm{ppb}$ served as positive control for strains DPD2794 (17) and DPD1718 (26). Nalidixic acid $100 \mathrm{mg} / \mathrm{L}$ served as the positive control for strain K802NR (23) while $0.5 \mathrm{mM}$ phenol served as positive control for DPD2544 (28).

\section{Conventional methodologies}

On October $10^{\text {th }}, 2017$, one day before the fish death event, the Ashdod-Yavne regional association for environmental protection had collected 7 samples from the river and tested the concentration of coliforms using standard method SM 9222 D, which includes Membrane filtration in the presence of chlorine in order to detect fecal coliforms. The raw data was summarized in report 380061 (29).

\section{Conventional subcontract methodologies}

On October $11^{\text {th }}, 2017$, after the dead fish were spotted in the river, but before the removal of the barrier separating the river and the Mediterranean Sea, the Ashdod-Yavne regional association for environmental protection has commissioned BACTOCHEM (www.bactochem.co.il) to collect samples from 8 different sites along the river and analyze them according to ISO/IEC 17011: 2004 standards. These are summarized in final report $384442(30)$.

\section{$B O D$}

BOD, biochemical oxygen demand, was tested through method SM 5210 B, a 5-day BOD test, which consists of filling an agreed sized bottle with sampled water and incubating it for 5 days. Dissolved oxygen (DO) is tested before and after incu- 


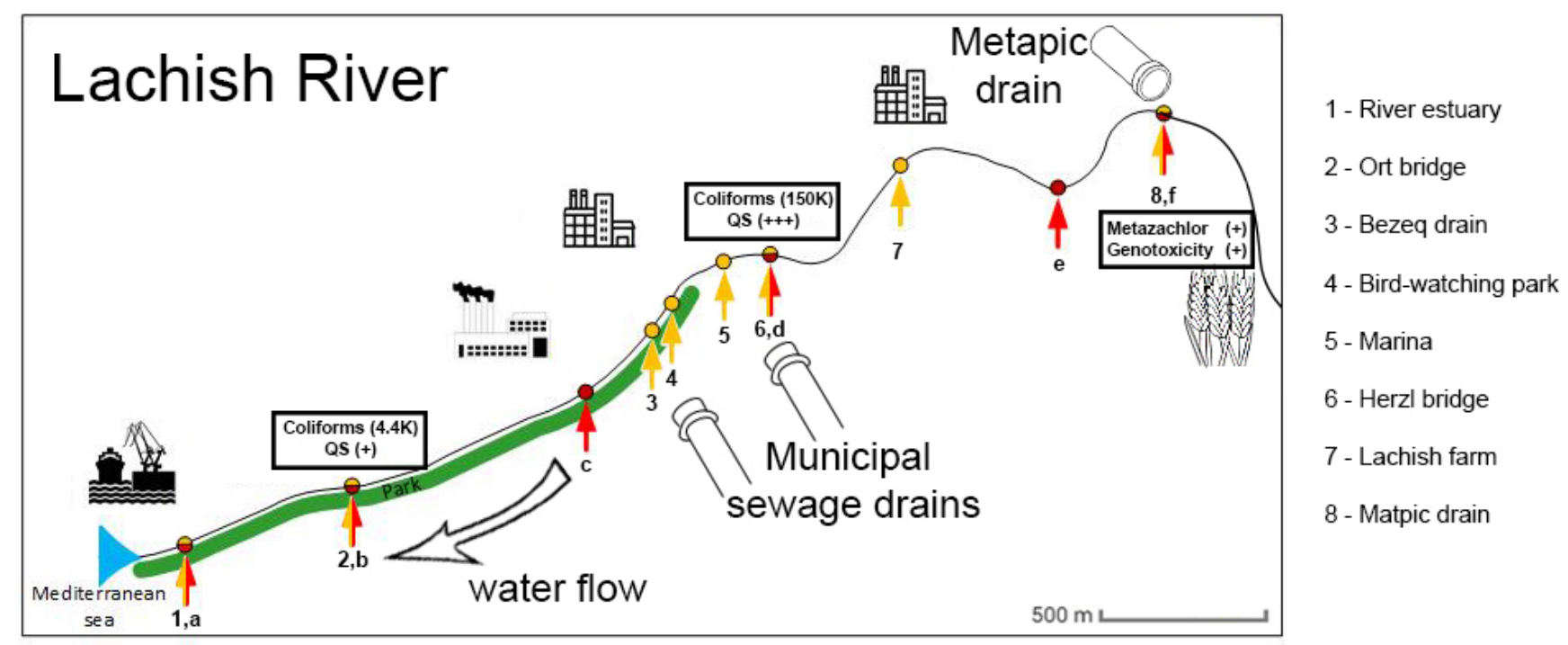

Figure 1. A schematic map of the Lachish River. Letters describe the sites tested using whole cell biosensor, sites numbered were tested using conventional methods. It should be noted that both teams (Ashdod-Yavne cities association for environmental quality control and Ben Gurion University) did not coordinate testing site collections because these collection events were made without each other's knowledge. However, it became obvious that pooling our data together would be a helpful endeavor. At Site 8 , f the bioluminescence whole cell based sensor indicated a genotoxic influence, conventional methods revealed the presence of Metazachlor, that is suspected for being genotoxic; site 6,d high concentrations of coliforms were found, findings from the biosensor suggested the presence of quorum sensing molecules; with the decrease in coliform concentration towards site $2, \mathrm{~b}$ and farther at site $1, a$, the indication for quorum sensing molecules, by the bioluminescence bacteria biosensor, decreased.

bation, and the BOD value is calculated from the difference between initial and final dissolved oxygen values (31). The dissolved oxygen was tested using method SM 4500 OC, including Azide modification, which impedes biological activity, thus reducing interference of iodide used in this method (32).

\section{Conductivity}

Conductivity was detected with method SM 2510 B, a laboratory method where the conductance of a $\mathrm{KCl}$ standard solution was measured, and a cell constant was calculated in agreement to the measured conductivity. Once the cell constant was determined and set to a conductivity meter, it was displayed as the conductivity of an unknown solution (33).

\section{Oils and fats}

Oils and fats were examined using SM 5520 B, a partition-gravimetric method, where dissolved or emulsified oils were extracted from the water using an extracting solvent. The solvent was then evaporated, and the difference between the weight before and the weight after evaporation indicated the amount of oils and fats (34).

\section{Partial metal scan}

Arsan, Cadmium and lead were screened using method SM $3120 \mathrm{~B}$, based on inductively coupled plasma emission spectroscopy. The emission spectra were then analyzed by monochromator or polychromator (35).

\section{Ammonia}

Ammonia was tested using titration method SM 4500 NH3C, where the ammonia was titrated with standard acid, while working with an indicator consisting of methyl red and methylene blue (36).

\section{Herbicides}

Herbicides and pesticides were tested through gas chromatography or mass spectrometry (30).

\section{$p H$}

$\mathrm{pH}$ was measured in method SM $4500 \mathrm{H}+\mathrm{B}$, which is an electrometric $\mathrm{pH}$ measurement (37).

\section{Phosphorus}

The test for phosphorus is not mentioned in the analysis report, and described as an "in house" kit based procedure (30).

\section{TOC}

Total organic carbon was assessed through method SM 5310 B, a high temperature combustion method, where the water was homogenized and vaporized, and the remaining carbon was oxidized into $\mathrm{H} 2 \mathrm{O}$ and $\mathrm{CO} 2$. The formed $\mathrm{CO} 2$ was then measured by a nondispersive IR analyzer or titrated coulometrically (38).

\section{TSS}

TSS, total suspended solids, were dried and measured in two methods, SM $2540 \mathrm{D}$ and $\mathrm{E}$, at $103-105^{\circ} \mathrm{c}$ and $550^{\circ} \mathrm{c}$, respec- 
tively. The samples were filtered through a glass-fiber filter and the deposit on the filter was dried at high temperature. The TSS was calculated through the difference between total dissolved solids and total solids (39).

\section{Turbidity}

The turbidity of the samples was determined with method SM $2130 \mathrm{~B}$, a nephelometric method, which is based on the comparison between the intensity of light scattered by the sample, and the light scattered by a standard reference. The turbidity is considered to be higher as the intensity increases (40).

\section{Data analysis}

The kinetic bioluminescent signal of the bacterial response to the various environmental water samples was expressed as the induction factor (IF), which was calculated using the formula: induction factor $=\mathrm{Bi} / \mathrm{Bc}$, where $\mathrm{Bi}$ is the maximum of the bioluminescent signal of the tested samples and $\mathrm{BC}$ the maximum signal of control.

\section{Results}

\section{Description of the event}

On October 11th, 2017, thousands of dead fish were detected floating on the Lachish River. In response to this event, the barrier separating the river from the Mediterranean Sea was removed, enabling dilution of the putatively contaminated water into the sea. Municipal representatives suggested oxygen deprivation and an increase in organic material as the main causes of contamination, possibly due to the runoff of sewage from Ashdod city and contaminants from the adjacent industrial plants during the first rain, which occurred two days earlier (41). While we present the official conventional testing procedure, we found interest in bringing an alternative and possibly complementary bioassay to the water analysis, which comprised of a whole cell bioreporter analysis.

\section{Conventional analysis.}

Once the pollution event had been detected, a team from the Ashdod-Yavne cities association for environmental quality control was sent to inspect the area, and Bactochem representatives were sent to collect samples (see Fig. 1) and run conventional analyses, to assess a given set of parameters in the water quality, in the hope of gaining some insight regarding the actual source of the pollution (Table 2). On the other hand, the Ben Gurion University authors had gained access to the river, just two days after the event, which was on the 13th of October, therefore, it is important to point out that the samples cannot be considered comparable, as the collection points were neither exactly the same nor were they the same water samples as they were post-Mediterranean Sea diluted.

These results present a significantly high concentration of coliforms, with the highest concentration recorded at site 6 which decreases in both directions, downstream in the direction of the sea and upstream, towards the end of the river (Fig 1). In addition, high BOD and conductivity values were ob- served, both increasing as the samples were collected at sites closer to the Mediterranean Sea. High values of total organic carbon were measured in the water, which increased as the samples were collected farther upstream. Low levels of oxygen were also observed all along the river collecting sites. The values of ammonia detected were high at sites 3,4 and 8, and at site 1 . Metal screening for arsenic, cadmium and lead were performed using conventional methods, these were not detected in high concentrations in the water, except for lead that was found at site 8 , in a concentration higher than the environmental guideline's limit.

Furthermore, in a screening for suspected pesticides and herbicides, the herbicides Atrazine and Metazachlor were detected only at site 8 . All samples collected from all sites, presented $\mathrm{pH}$, phosphorus and TSS levels within normal limits.

\section{Bacterial kinetic reaction}

Fig. 2 demonstrates the response of the different bioluminescent bacterial strains to the Lachish water samples, collected from the various collection points. In this study, five bacterial strains have been used for evaluating water toxicity, while each strain is sensitive to a different stress. In general, three different response patterns may be observed, which are: induction, inhibition and no visible effect.

The reaction of luminescent bacteria, when measured kinetically, shows distinct characteristic activity based on its environment. Kinetic reactions of the bacteria stains were measured and presented in Fig. 2.

Each of Fig. 2 (A-E), shows the behavior of a bacteria strain as an effect of samples from the Lachish River. It should be noticed that every figure's $x$ axis shows the time of reaction scaled relevant to the same strain, as each strain has its own unique luminescence response to its surrounding.

There are three notable trends of behavior of the reporter bacteria present; Fig. 2A and E show induction in light intensity; Fig. $2 \mathrm{~B}$ and $2 \mathrm{C}$ show that the bacteria produce lower light intensity when exposed to the Lachish river samples; and Fig. $2 \mathrm{D}$ shows slight induction by the environmental samples, but between collection points, the light intensity is the same. In addition, Fig. 2A, 2B, and $2 \mathrm{C}$ present a decrease in light intensity as the samples are closer to the sea.

\section{Bacterial induction analysis}

The light response for each bacterial strain was analyzed using the calculation of induction factor $=\mathrm{Bi} / \mathrm{Bc}$, where $\mathrm{Bi}$ is the maximum of the bioluminescent signal of the tested samples and $\mathrm{Bc}$ the maximum signal of control. The results are presented herein.

Bacterial strains TV1061 and DPD2794 presented a decrease in the Induction factor, while K802NR, DPD2544 and DPD1718 presented an increase in induction factor.

Induction values calculated for TV1061 were relatively low, beginning with $0.69 \pm 0.17$ in site $f$ and $0.26 \pm 0.06$ in site $a$, and the same trend was observed for DPD2794, which presented a decrease in induction from $0.56 \pm 0.03$ in site $\mathrm{f}$ to $0.18 \pm 0.008$ in site a. 
The three remaining bacteria presented induction; samples from sites e-f tested with strain DPD2544, presented similar induction factors of $1.37 \pm 0.09-1.33 \pm 0.06$, and a decrease was observed for sites $b$ and $a$. Another bacterial strain that presented induction was $\mathrm{K} 802 \mathrm{NR}$, which presented a decrease in induction from $1.31 \pm 0.22$ in site $\mathrm{f}$ to $0.86 \pm 0.18$ in site a. DPD1718 presented induction as well, as sites a-d presented similar IF values around $1.39 \pm 0.067$, and sites e and $f$ presented IF of $1.32 \pm 0.03$ and $1.23 \pm 0.12$, respectively.

\section{Discussion}

\section{Conventional analysis}

The data shown in Table 2 indicates that the highest number of coliforms was measured at sample site 6 , adjacent to the municipal wastewater outlet, and it decreased to lower values downstream as well as upstream (sample site 1, Fig. 1). The proximity between the sea and the river could explain the increase in conductivity (salinity) near the estuary, as well as the decrease in bacterial counts, which could have been affected by the salts delivered from the sea. This result could indicate

Table 2. Results of the water conventional testing of the water samples collected at the different sampling sites along Lachish River

\begin{tabular}{|c|c|c|c|c|c|c|c|c|c|c|c|}
\hline & \multirow{2}{*}{ units } & \multicolumn{8}{|c|}{ Sampling site } & \multirow{2}{*}{$\begin{array}{c}\text { Environ- } \\
\text { mental } \\
\text { guideline }\end{array}$} & \multirow{2}{*}{$\begin{array}{l}\text { Method } \\
\text { performed }\end{array}$} \\
\hline & & 1 & 2 & 3 & 4 & 5 & 6 & 7 & 8 & & \\
\hline Coliforms & $\mathrm{cfu} / \mathrm{ml}$ & 870 & 4400 & 5100 & 26000 & 78000 & 150000 & 42000 & $\begin{array}{c}\text { not } \\
\text { tested }\end{array}$ & $<8(42)$ & SM9222D \\
\hline BOD & $\mathrm{mg} / \mathrm{L}$ & 8.7 & & 6.9 & 7.5 & & & & 2.5 & $<4(43)$ & SM5210B \\
\hline $\begin{array}{l}\text { Dissolved } \\
\text { oxygen }\end{array}$ & $\mathrm{mg} / \mathrm{L}$ & 1.1 & & 0.9 & 0.8 & & & & 1 & $>3(42)$ & SM4500 OC/SM \\
\hline Conductivity & $\mu \mathrm{s} / \mathrm{cm}$ & 17130 & & 16500 & 12700 & & & & 850 & $\begin{array}{c}<1500 \\
\left(20^{\circ}\right)(44)\end{array}$ & SM2510B \\
\hline $\begin{array}{l}\text { Gravimetric } \\
\text { oils and fats }\end{array}$ & $\mathrm{mg} / \mathrm{L}$ & $<5$ & & $<5$ & $<5$ & & & & $<5$ & $<1.5(42)$ & SM5520B \\
\hline Arsenic & $\mathrm{mg} / \mathrm{L}$ & $<0.010$ & & $<0.010$ & $<0.010$ & & & & $<0.010$ & $\begin{array}{c}<0.01 \\
(42)\end{array}$ & SM3120B \\
\hline Cadmium & $\mathrm{mg} / \mathrm{L}$ & $<0.005$ & & $<0.005$ & $<0.005$ & & & & $<0.005$ & $\begin{array}{c}<0.025 \\
(42)\end{array}$ & SM3120B \\
\hline Lead & $\mathrm{mg} / \mathrm{L}$ & $<0.005$ & & $<0.005$ & 0.007 & & & & 0.096 & $\begin{array}{c}<0.04 \\
(42)\end{array}$ & SM3120B \\
\hline $\begin{array}{l}\text { Ammonia } \\
\text { (NH3C) }\end{array}$ & $\mathrm{mg} / \mathrm{L}$ & 0.6 & & 3.7 & 1.5 & & & & 2.9 & $\begin{array}{c}<0.233 \\
(45)\end{array}$ & SM4500 NHLC \\
\hline Atrazine & $\mathrm{mg} / \mathrm{L}$ & n.d. & & n.d. & n.d. & & & & 0.0005 & $\begin{array}{c}<0.002 \\
(42)\end{array}$ & \\
\hline Diflufenican & $\mathrm{mg} / \mathrm{L}$ & n.d. & & n.d. & n.d. & & & & $\begin{array}{l}\text { below } \\
\text { LOQ }\end{array}$ & & \\
\hline Metazachlor & $\mathrm{mg} / \mathrm{L}$ & n.d. & & n.d. & n.d. & & & & 0.0013 & $\begin{array}{c}<0.0001 \\
(46)\end{array}$ & \\
\hline $\mathrm{pH}$ & $\mathrm{pH}$ units & 7.52 & & 7.33 & 7.29 & & & & 7.27 & $\begin{array}{l}6-8.5 \\
(30)\end{array}$ & SM4500 H+B \\
\hline Phosphorus & $\mathrm{mg} / \mathrm{L}$ & 0.18 & & 1.15 & 0.36 & & & & 0.44 & $<2(42)$ & $\begin{array}{l}\text { Kit based in } \\
\text { house } \\
\text { procedure }\end{array}$ \\
\hline $\begin{array}{l}\text { Total organic } \\
\text { carbon }\end{array}$ & $\mathrm{mg} / \mathrm{L}$ & 31.66 & & 26.6 & 43.5 & & & & 81 & $<15(45)$ & SM5310B \\
\hline $\begin{array}{l}\text { TSS in } 103 \text { up } \\
\text { to } 105\end{array}$ & $\mathrm{mg} / \mathrm{L}$ & 11.5 & & 19.5 & 12 & & & & 14 & $<15(42)$ & SM2540D \\
\hline TSS in 550 & $\mathrm{mg} / \mathrm{L}$ & $<1$ & & $<1$ & $<1$ & & & & $<1$ & $<15(42)$ & SM2540E \\
\hline Turbidity & NTU & 20 & & 19.8 & 23.1 & & & & 41.2 & $<20(45)$ & SM2130B \\
\hline
\end{tabular}



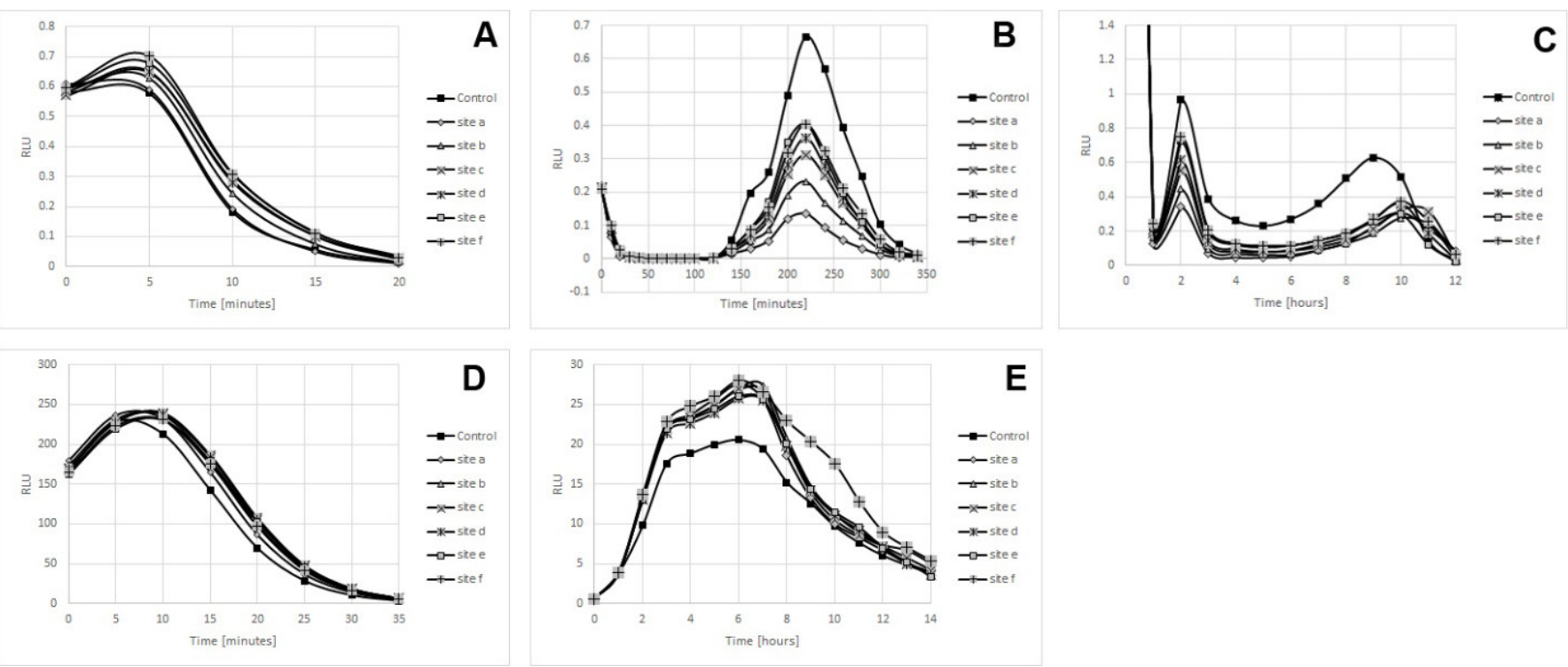

Figure 2. Kinetic luminescence response of bacteria to samples. A is K802NR strain response, B is TV1061 strain response, C is DPD2794 strain response, D is DPD2544 strain response, and E is DPD1718 strain response.

sites 3 and 6 (the "Bezeq Drainage" and "Herzl Bridge"), as the contamination's sources. A possible source of coliform contamination may be the overflowing of both municipal and industry related sewage, which previously had been known as causes of pollution of the said river (47). Collection site 7 presented a lower concentration of coliforms, since it is upstream from the sewage port. Obviously, as only coliforms were tested, and these may only be a small part of the microbiological environment in the river, we do not have the overall microbial count, therefore, the total bacterial concentration was in fact higher. We should note, herein, that their origin is mainly sewage and not industrial contaminants such as pesticides or other organic pollutants.

Another indicator for possible environmental pollution, would be the high biochemical oxygen demand (BOD) values of the tested samples. BOD is the amount of oxygen required for the overall microbial metabolism of organic compounds in water. This demand is measured over a period of time, and is affected by temperature, nutrient concentrations, and the enzymes available to the indigenous microbial populations (48). In this case study, BOD values increased in the water from site 8 , which contained the lowest value, to the highest value in site 1 . This is logical, if we do not take into consideration the fact that site 6 has such a large quantity of coliforms. Howev$\mathrm{er}$, as this site was not tested for BOD by the municipality, we cannot discuss this putative point. Dissolved oxygen depletion along the river is most likely evidence for the large microbial population status, which is in response to the high concentration of organic material found in the river from various postrain runoffs and sewage. Thus, increase in BOD correlates here with the decrease in coliform concentration, while it correlates with the increase in TOC (49).

As stated before, the conductivity herein may simply be caused by the presence of dissolved salts in the sea water transferred into the river. This also indicates how far the seawater reached into the Lachish River. Indeed, the highest conductivity value tested was at sampling site 1 , the closest site to the seawater. Furthermore, as sampling distance increased from the seashore, the conductivity value decreased (44).

An additional parameter tested in this case is ammonia, a toxic compound which affects the central nervous system of fish and can eventually lead to death (50). Although both species of ammonia can cause toxicity, the unionized form is of greatest concern, especially to freshwater fish such as salmonids (51). As water becomes more alkaline, the $\mathrm{NH} 3$ ratio increases exponentially, and with every $10^{\circ} \mathrm{C}$ increase in temperature, the $\mathrm{NH} 3$ ratio increases tenfold (52). At ambient water, temperature of $20^{\circ} \mathrm{C}$ and a pH between 7 and 8 , naturally occurring unionized ammonia can range between 0.0004 and $0.004 \mathrm{mg} / \mathrm{L}(53,54)$. Higher concentrations of unionized ammonia suggest the effects of anthropogenic activity and organic pollution $(53,54)$. Ammonia is a non-conservative constituent and one of the components of the nitrogen cycle. In freshwater, ammonia is converted to nitrite (NO2-), and then to nitrate (NO3-) by nitrifying bacteria. These compounds stimulate growth in organisms, and cause eutrophication, which leads to hypoxia (50). Nitrates are another source of nitrogen toxicity in the environment and at very high concentrations can be detrimental. In this current event, the values of ammonia may originate from municipal wastewater and in addition may indicate the presence of microbial population, and not a product of chemical industry.

Pesticides and herbicides are commonly tested in water pollution events, due to their vast usage in agriculture and their ability to travel from cultivated fields to water sources through runoff or rain (55). Atrazine and Metazachlor are herbicides that were found only in collecting point 8 , the Metapic drain, which is responsible for the industrial zone of the city. The drain is located at a part of the river with minimal flowing waters, meaning the amount of herbicides inside the river is smaller 
than that actually detected in the drain. Both herbicides are classified as endocrine disruptive chemicals (EDC), which affect regular endocrine function by changing hormone amounts and prevent the interaction between an existing hormone and its receptor (56). They are both toxic to humans and can lead to irritation and respiratory sensitization, genotoxic damage and cancer (57). Furthermore, both herbicides are hazardous to the aquatic environment $(39,40)$, and atrazine can cause organ damage. Their presence in the river suggests that there is another possible source of pollution besides the overflowing sewage (60). The origin of these herbicides could have been the crop fields east of the stream, as herbicides could have been washed by the first rain, and collected into the river. Another possible origin may be industries near point 8 , where a spillage of these chemicals could significantly damage the ecosystem. The herbicides' concentrations shown in Table 2 are harmful to marine life $(42,46)$, although still fairly low, but when considering the distance between collection point 8 and the stream, it is possible the effect was not significant.

Another substance tested is Phosphorus. In water it is not considered to be directly toxic to humans and animals (61), however, it can accelerate eutrophication, which restricts water use for fisheries, recreation, industry, and drinking, due to the increased growth of undesirable algae, aquatic weeds, and oxygen shortages, caused by their death and decomposition (62). This could be supported by the elevated levels of total organic carbon, which will eventually lead to the depletion of oxygen, as a result of consumption. Aquatic life may be hampered when the entire water body experiences daily fluctuations in dissolved oxygen levels as a result of nocturnal plant respiration. Extreme oxygen depletion can lead to the death of desirable fish species. Also, periodic blooms of cyanobacteria and other harmful algal blooms contribute to a wide range of water-related problems, including summer fish kills (62). Summer fish kills refers to the formation of several oxygen layers in the water during summer, due to a temperature rise. After the first rain, cool, dense water reaches the bottom of the lake, creating a mixture of the anoxic water from the bottom and the oxygen rich rainwater. This phenomenon decreases oxygen levels in the river and harms aquatic life (63).

Total suspended solids (TSS) in the river were tested as well. TSS indicates the total weight of materials left after evaporation at $105^{\circ} \mathrm{C}$ or $550^{\circ} \mathrm{C}$. High TSS denotes a large amount of pollutants in the water, and could correlate with turbidity (64). Turbidity can indicate the presence of contaminated surfaces or soils, and could suggest an increase in organic matter, which contributes to bacterial growth (65). The turbidity and TSS presented in this case do not correlate, but TSS does correlate with TOC. It is possible that turbidity was affected by the depth of the river, thus, upstream as it gets shallow, more material from the ground is suspended in the water.

Lastly, other parameters besides chemicals can provide a reason for environmental changes of the water surface conditions. Some physical parameters (e.g., water temperature, flow rate, $\mathrm{pH})$ may have direct effect on the water quality. For example, increased flow rate caused by rain could increase turbidity with no relation to bacteria (66), an increase in water temperature as a result of drainage, or environmental changes, could impair organisms metabolism, thus elevating oxygen demand (10).

The results exhibited in Table 2 present absolute values of specific chemicals in the water, without the determination of a biological effect, which cannot be properly determined by conventional methods, since low levels of different substances, or byproducts, can lead to hazardous combinations. For instance, some pesticides are much more toxic in a mixture than alone (67), this principal was observed on various EDCs and nonylphenol at the Aire river (68).

With the absolute values of the detected substances it is now possible to assess the biological effect of the samples using the whole cell bacteria sensing method, and see whether both methods correlate.

\section{Bacterial kinetic reaction}

During the procedure, the bioluminescent bioreporter bacteria were exposed to the various samples collected ('letter' sites), and their kinetic response was monitored and measured over time. In effect, the light intensity measured is an indication of a specific metabolic system (via a given promoter connected to the lux operon) in each of the panel bacterial strains as well as its overall vitality. Analyzing the kinetic signal can provide insight regarding the biological effect each sample has, via the given promoters that did react to the analytes in the sample. Analysis of environmental samples using whole cells biosensors may also indicate the severity of pollution, even if the cause or pollutant identity is unknown. Comparing the individual bacterial indicators glow kinetics in presence of the different environmental samples, to "clean", controlled water, reveals a behavior with statistical significance to unknown pollutants.

K802NR strain's (A) LasI promotor is transcribed in response to the presence of long chain AHLs, which are quorum sensing active molecules (69). The increase in induction as the samples are farther upstream can be explained if more producing AHLs bacteria are present in the waters upstream towards site $f$, and is supported by the findings shown in Table 2, where higher coliform concentration is present upstream. TV1061 strain (B) is engineered so under environmental stresses with heat shock like effect on the membrane, it increases luminescence after approximately 25 minutes of exposure (70). Its response (Fig. 2B) indicates there is indeed no indication for heat shock like response, but there is another factor that harms the growth or metabolism of the bacteria, and it is more intense closer to site a, as the sample is closer to the shore. The strain DPD2794 is infused with recA promotor to induce light when a DNA repair action is taken place (17). In the presence of the samples from the Lachish River, the strain demonstrates no induction of light intensity, on the contrary, there is a deduction. According to strains TV1061 and DPD2794, the biological effects from the samples in Lachish River are not genotoxic, nor cytotoxic. The decrease in light intensity of these two strains could be explained by salts coming from the Mediterranean Sea, as said before, the samples collect- 


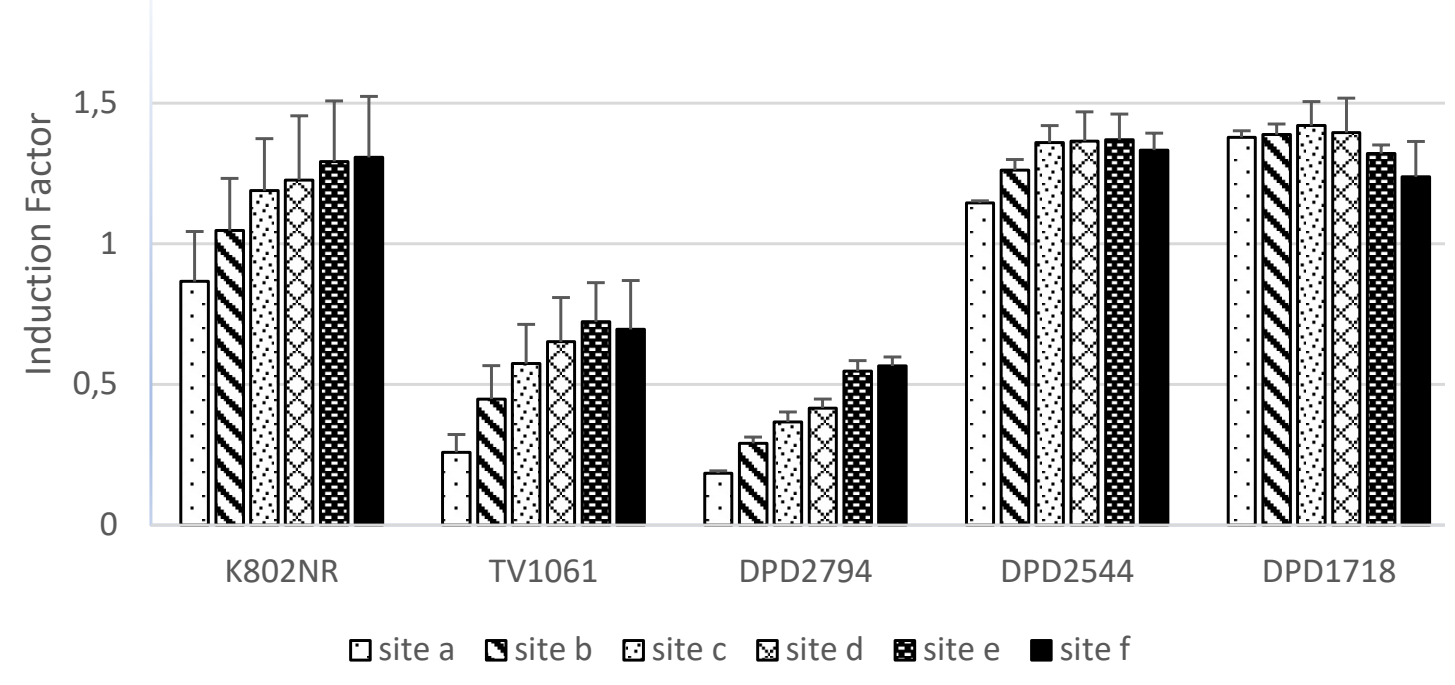

Figure 3. Induction factor of each bacterial indicator as effected by site $(n=3)$.

ed for the biological tests were retrieved after the barrier at the Mediterranean Sea was removed in order to dilute the river after the pollution occurred. DPD2544 is sensitive to the presence of unsaturated fatty acids. Fatty acids constitute the membranes of organisms, thus, with the mortality of bacteria, fatty acids will be released into the stream. Since live coliforms are present, it is reasonable to assume the presence of dead coliforms as well, which are responsible for the release of fatty acids. Moreover, fatty acids could have also originated from the runoff from the Ashdod city and industrial plants.

The last tested strain is DPD1718, which has the same recA promotor as DPD2794. However, in the case of DPD1718, the promoter was integrated into the lacZ operon of a DPD1962 E. coli strain, in an orientation that can allow the transcription of the lacZ operon (23). Interestingly, when observing the kinetics of DPD1718, there is a difference in its response between the samples collected from site $\mathrm{f}$ and the rest of the sites. This is an indication that there is another substance in the sample of site $f$ that has genotoxic properties. This can be explained by the presence of atrazine and metazachlor that were detected only in site 8 (shown in Table 2).

Since both DPD2794 and DPD1718 contain the same promoter, it would have been expected of strain DPD2794 to present induction as well. It is possible that DPD2794 is more sensitive to salts in the water, thus their effect was more significant than that of the herbicides. This difference between the strains, along with the minor concentration of herbicides in the water, indicate DPD1718 as a sensitive and more resilient strain.

After understanding the reaction trends of the bacteria, we can examine the calculated amplitudes, and assess the severity of the contamination according to the bacterial reactions.

\section{Bacterial induction analysis}

The engineered bacterial strains are affected in two ways by the surrounding stresses. A harmful surrounding will decrease the cells viability and hinder the metabolic process, thus decrease light intensity, while for each strain there are typical materials that increase the expression of the plasmid and increase light production. These effects have been shown to correlate with concentration of various toxicants $(16,20)$, thus, measurement of light production intensity from the engineered bacteria response can give an indication of both type of stress present in the environmental samples, and the severity of its presence (see Fig. 3).

The induction factor values observed for strains TV1061 and DPD2794 suggest that the contamination had a more significant effect on DPD2794 than on TV1061. The low values of induction factor calculated for both strains indicate the water's highly negative effect on the bacteria, and could eliminate the presence of genotoxic and cytotoxic substances in the water, since DPD2794 and TV1061 react to genotoxicity or cytotoxicity, respectively. It appears that a different toxicant affected the bacteria's metabolism, thus causing reduction in light intensity. Since the samples were collected after dilution from sea water and again diluted into the bacterial solution, it is safe to assume that oxygen deprivation did not affect the bacteria, and other factors may have caused the inhibition in light production, such as high salt content, that had affected the bacteria more intensely in the presence of samples collected closer to the sea shore.

The remaining bacteria presented induction, and can assist in further understanding the symptoms of the pollution. DPD2544 is known to produce luminescence in the presence of unsaturated fatty acids (20). In addition, previous experiments have described the bacteria as a possible indicator for general toxicity (21). The induction presented for this strain could suggest a rise in fatty acid content in the water in most parts of the stream, up to a significant dilution, which occurred close to the estuary. Fatty acids are partially soluble in water, and not easily biodegradable (64), an abundant presence of fatty acids can lead to the formation of a blocking layer on the water surface, preventing oxygen from reaching the water, thus causing the death of any aerobic 

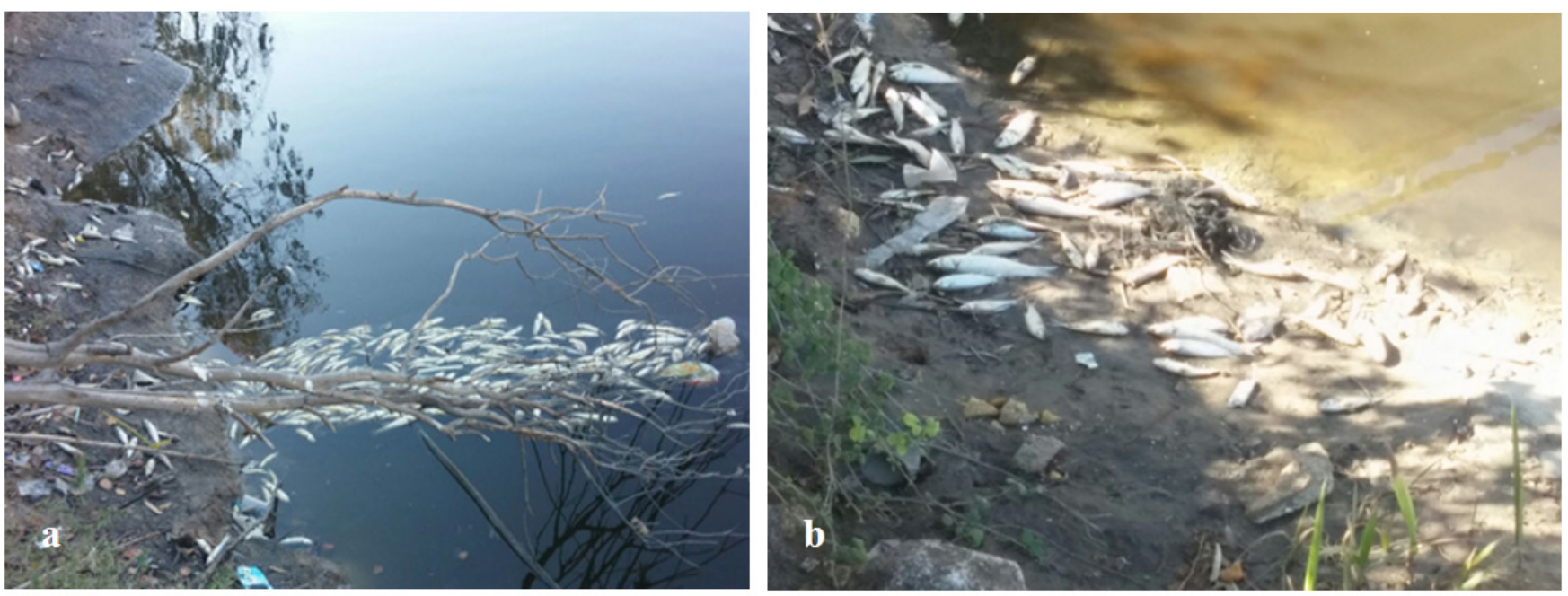

Figure 4. Pictures taken from the Lachish River, on October 13th, 2017. 4a: Dead fish in collection point c, 4b: Dead fish under Herzl Bridge, Collection Point f/8. (T. Axelrod)

aquatic life present in the river (64). Low values of dissolved oxygen and high BOD values were presented in the chemical analysis conducted, and both indicate a decrease in oxygen levels in the water and an oxygen distress of aquatic life $(48,71,72)$. The cause of these conditions may be the combination of an increase in bacteria from sewage pollution, and the runoff of fats and oils from industrial plants.

Another strain which presented induction is K802NR, which is activated by quorum sensing molecules. Connection between bacteria via quorum sensing can occur as a response to an increase in population density (19) which correlates with the rise in coliforms detected by chemical analysis. As indicated earlier, the decrease in coliforms alongside the river could be a result of the signaling between the bacteria, alerting the increase in population. Farther downstream, inhibition was shown that could be related to distress caused by the rising salt concentration coming from the sea water.

As mentioned before, both strains DPD1718 and DPD2794 indicate the presence of mutagenic substances, while it is possible strain DPD2794 is more sensitive to salt and as a result, did not present induction. The lower induction values for this strain in sites e and $f$ could be explained by the presence of herbicides detected in the water, making them more toxic to the bacteria, thus decreasing light emission. Although it is seen in Fig. 2 that kinetically, there is a distinct reaction towards the sample collected from site $f$.

Various types of whole cell based biosensors have already been developed $(14,16)$. In previous studies, samples from the Lachish River pollution from 2009 were collected and analyzed using bioluminescent bacteria whole cell biosensors. Analysis of strain TV1061's response to the environmental water samples presented an inhibition, as in the present case (14). According to authorities, the polluted waters contained herbicides and presented high levels of BOD, which sits well with the findings in the current case study, where herbicides and high BOD levels were also detected in the samples collected upstream (73).

\section{Conclusions}

For decades, the Lachish River has suffered numerous cases of pollution, originating from the population surrounding it. In several cases the pollution was attributed to sewage spillage, factory incident, and accumulated pollution drifted by rains. This case study aimed to evaluate the characteristics and effects of the pollution in the river, which occurred on October $11^{\text {th }}$, 2017, using bioluminescent bacterial indicators as biosensor while validating results from traditional methods.

Luminescence bacteria based sensors have proved to effectively indicate the presence of pollutants in the Lachish River. From the analysis of the bacteria's behavior, it appears that the collected water from the Lachish River may have contained quorum sensing related molecules, fatty unsaturated acids, and at least one more substance that has genotoxic characteristics in site f. Moreover, the data produced eliminated concerns of the presence of cytotoxic substances. Although overall levels of toxicity did not seem to be extremely high, the dilution of the river with the Mediterranean Sea water, before samples could be taken for testing with Luminescent bacteria based biosensors, and the two days interval between the time of the event and the collection of samples should be taken into consideration. Thus, every level of contaminant identified in the water may have been much higher during the time of the contamination, and salt concentrations must have been lower. The data acquired from the bacterial indicators was validated using conventional analysis methods, revealing elevated levels of coliforms, BOD, total organic carbon, and the presence of Atrazine and Metazachlor herbicides in site 8 (f). High values of conductivity were attributed to salts originating from the Mediterranean Sea. A genotoxic response was measured in site $\mathrm{f}$, attributed to a minor leak reported from Metapic drain, which has shown to contain traces of Atrazine and Metazachlor.

The results show a picture (Fig. 1) of a river polluted with high levels of coliforms, high BOD values, and elevated organic materials concentrations in the waters, which are attributed to 
the rain overflooding the sewage pipes and carrying oils from Ashdod city. However, the rain was not strong enough to allow the river to break through the natural sand barrier into the sea, and enable dilution of the river, causing entrapped bacteria to thrive and deplete oxygen in the river water, leading to mass fish mortality (9). Small amount of herbicides from Metapic drain (a centralized drain of the northern industrial zone) could have reached the Lachish River as well, but it is unlikely to be the leading cause of death of all the fish, as the leak occurred 2 days before the sighting of the floating fish, and the effect of herbicides would have been faster.

The luminescent bacteria based sensor bioassay provided indication of the presence of unknown chemicals and hazards, and revealed information regarding the biological effects of the pollution, which cannot be detected by conventional methods. These findings were validated with the results of conventional analysis that detected suspected contaminants. Whole cell based sensors could be highly useful in continuously monitoring water sources, as presented in previous works $(14,74)$, to detect pollution at an early stage of an event and prevent severe consequences.

By testing the bacteria's response to a variety of toxicants, a vast data base could be created, and potentially provide a rapid and cost-effective method of analyzing environmental samples for toxicants, while also providing insight on the biological effects of the pollutants.

\section{Acknowledgments}

We would like to thank Yakov Palachi, from the Ashdod municipality and Gad Opher, from the Ashdod-Hevel Yavneh Regional association for environmental protection, for contributing their insight on the event and providing the data from all the conventional methods tests.

The Kreitman School of Advanced Graduate Studies at Ben Gurion University is acknowledged for supporting Tim Axelrod through the Zin fellowship.

\section{References}

1. Zalul. Lachish River identity card [Internet]. Available from: http:// www.zalul.org.il/?page_id=383

2. Mapa site. Lachish River park [Internet]. Available from: http://

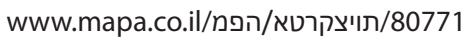

3. Gabbay S. Rehabilitation of Israel's Rivers. Israel Information Center; 2001. 1-7 p.

4. Ashtukar O. The Lachish River - the never ending story. ashdodnet [Internet]. 2015; Available from: https://www.ashdodnet.com/article/61353

5. Zalul. Category archive: the Lachish River. 2017; Available from: http://www.zalul.org.il/?cat=30

6. Datz E. Another obstacle in the restoration of the Lachish River. Walla news [Internet]. 2009; Available from: https://news.walla. co.il/item/1425965

7. Ashtukar O. Historical: the health department has authorized sailing in the Lachish River. ashdodnet [Internet]. 2014; Available from: http://www.ashdodnet.com/article/53147

8. Ashtukar O. The office of environmental protection: the Lachish River is one of the three cleanest rivers in Israel. ashdodnet [Internet]. 2017; Available from: https://www.ashdodnet.com/arti- cle/252481/3

9. Curiel I. Tzuri M. Pollution kills thousands of fish in Lachish River. Ynet news [Internet]. 2017; Available from: https://www.ynetnews.com/articles/0,7340,L-5027357,00.html

10. Owa F. Water pollution : sources, effects, control and management. Int Lett Nat Sci. 2014;3:1-6.

11. Beauchemin D. Inductively Coupled Plasma Mass Spectrometry. 2008;78(12):4111-36.

12. Velikonja Bolta Ŝ. Zupanĉiĉ-Kralj L. Marsel J. Gas chromatographic determination of formaldehyde in air using solid-phase microextraction sampling. Chromatographia. 1998;48(1-2):95-100.

13. Lawton LA. Edwards C. Codd GA. Extraction and high-performance liquid chromatographic method for the determination of microcystins in raw and treated waters. Analyst. 1994;119(7):1525.

14. Axelrod T. Eltzov E. Marks RS. Bioluminescent bioreporter pad biosensor for monitoring water toxicity. Talanta. 2016;149:290-7.

15. Eltzov E. Ben-Yosef DZ. Kushmaro A. Marks R. Detection of sub-inhibitory antibiotic concentrations via luminescent sensing bacteria and prediction of their mode of action. Sensors Actuators, B Chem. 2008;129(2):685-92.

16. Eltzov E. Yehuda A. Marks RS. Creation of a new portable biosensor for water toxicity determination. Sensors Actuators B Chem. 2015;221:1044-54.

17. Vollmer AC. Belkin S. Smulski DR. Van Dyk TK. Larossa RA. Detection of DNA damage by use of Escherichia coli carrying recA'::lux, uvrA'::lux, or alkA'::lux reporter plasmids. Appl Environ Microbiol. 1997;63(7):2566-71.

18. Arsène F. Tomoyasu T. The heat shock response of Escherichia coli. Int J food. 2000;55:3-9.

19. Miller MB. Bassler BL. Quorum sensing in bacteria. Annu Rev Microbiol. 2001;55:165-99.

20. Bechor O. Smulski DR. Van Dyk TK. LaRossa RA. Belkin S. Recombinant microorganisms as environmental biosensors: Pollutants detection by Escherichia coli bearing fabA'::lux fusions. J Biotechnol. 2002;94(1):125-32.

21. Meighen EA. Bacterial bioluminescence: organization, regulation, and application of the lux genes. FASEB J. 1993;7(11):1016-22.

22. Hubálek Z. Protectants used in the cryopreservation of microorganisms. Cryobiology. 2003;46(3):205-29.

23. Goh EB. Yim G. Tsui W. McClure J. Surette MG. Davies J. Transcriptional modulation of bacterial gene expression by subinhibitory concentrations of antibiotics. Proc Natl Acad Sci. 2002;99(26):17025-30.

24. American Society for Microbiology. Applied and Environmental Microbiology. 60(4). Evanston, Illinois: American Society for Microbiology; 1994. 1414 p.

25. American Society for Microbiology. Applied and Environmental Microbiology. 60(4). Evanston, Illinois: American Society for Microbiology; 1994. 2566 p.

26. Davidov Y. Rozen R. Smulski DR. Van Dyk TK. Vollmer AC. Elsemore DA. et al. Improved bacterial SOS promoter::Iux fusions for genotoxicity detection. Mutat Res - Genet Toxicol Environ Mutagen. 2000;466(1):97-107.

27. Miller JH. Experiments in molecular genetics. New York: Cold spring harbor laboratory press; 1972.

28. Premkumar JR. Lev O. Marks RS. Polyak B. Rosen R. Belkin S. Antibody-based immobilization of bioluminescent bacterial sensor cells. Talanta. 2001;55(5):1029-38.

29. Hanley A. Pruitt ES. Clean Water Act methods update rule for the analysis of effluent. Fed Regist. 2017;82(165):40836-941.

30. Bactochem. Final Report 384442. 2017. p. 1-4.

31. APHA (American Public Health Association). AWWA (American Water Works Association). WEF (Water Environment Federation). 5210 biochemical oxygen demand ( Bod ). Stand Methods Exam Water Wastewater. 2001;(5000):2-13. 
32. APHA-American Public Health Association. 4500-Oxygen (Dissolved): lodometric Methods. Stand Methods Exam Wastewater. 2005;(4000):136-43.

33. Greenberg AE. Clesceri LS. Eaton AD. Franson MAH. Method 2510. Stand Methods Exam Water Wastewater. 1992;552.

34. Nzila A. Thukair A. Sankara S. Abdur Razzak S. Characterization of aerobic oil and grease-degrading bacteria in wastewater. Environ Technol (United Kingdom). 2017;38(6):661-70.

35. Greenberg AE. Clesceri LS. Eaton AD. 3120 Metals by Plasma Emission Spectroscopy. Stand methods Exam water wastewater. 1992;552:34-40.

36. Eaton AD. Clesceri LS. Greenberg AE. Franson MAH. 4500-NH3 C. Titrimetric Method. Standard Methods for the Examination of Water and Wastewater. 2016. p. 4-75.

37. Greenberg AE. Clesceri LS. Eaton AD. Franson MAH. Method 4500H. Stand Methods Exam Water Wastewater. 1992;552.

38. Rice E. Baird R. Eaton A.. Clesceri L. 5310 Total Organic Carbon (TOC). Stand Methods Exam Water Wastewater. 2005;(5310):1-16.

39. Analitical E. Total Solids Dried at $103-105^{\circ} \mathrm{C}$. 1997;(2540):55-61.

40. Greenberg A. Clesceri L. Eaton A. APHA Method 2130: Standard Methods for the Examination of Water and Wastewater. 1992;552:1-11.

41. watch the photos: the first rain has arrived to Ashdod. Ashdod online [Internet]. 2017; Available from: https://ashdodonline. co.il/59032/דודשאל-עיגה-םשגה/201/Ab

42. Kennedy SD. Health of the people regulations (wastewater quality regulation and purification rules). 2011;816(28):1-23. Available from: https://www.google.co.il/url?sa=t\&rct=j\&q=\&esrc=s\&source $=$ web $\& c d=1 \& c a d=$ rja\&uact $=8 \&$ ved $=0$ ahUKEwjzq J3hqbTYAhWKyKQKHX9bAAIQFggnMAA\&url=https\%3A\%2F\%2Fwww. health.gov.il\%2FLegislationLibrary\%2FBriut01.pdf\&usg=AOvVaw2SWlgoAVBRJt6ykPKuZmmX

43. Twort AC. Ratnayaka DD. Brandt MJ. Water Supply. Oxford, UK: Butterworth-Heinemann; 2000. 200 p.

44. Twort AC. Ratnayaka DD. Brandt MJ. water supply. Oxford, UK: Butterworth-Heinemann; 2000. 206-207 p.

45. Brines evacuation procedure [Internet]. Ministry of Environmental Protection; 2010. Available from: http://www.sviva.gov.il/subjectsEnv/Wastewater/IndustrialWastewater/PollutionComponents/ Documents/NohalPinuyTimlachot.pdf

46. Frieder-Shoham E. Kress N. Gordon N. Monitoring the drainage of of Adama Agan, Paz Ashdod Refinery and the Bney Darom and Gan Yavne pickle factories. Isr Oceanogr Limnol Res Ltd [Internet]. 2014; Available from: http://www.sviva.gov.il/InfoServices/Res-

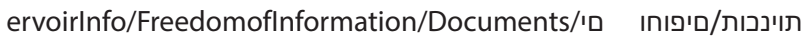
תוימוקמ רוטינ/NiturMekomiBaza2014.pdf

47. Kanti Y. The wonder that became a stench. Nrg Maariv [Internet]. 2006; Available from: http://www.nrg.co.il/online/1/ ART1/495/411.html

48. Weiner ER. Applications of Environmental Aquatic Chemistry - A practical guide. Applications of Environmental Aquatic Chemistry A Practical Guide. 2008. 98-99 p.

49. Zobell CE. Some factors which influence oxygen consumption by bacteria in lake water. Biol Bull. 1940;78(3):388-402.

50. Hoar WS. Randall DJ. Farrell AP. Anderson PM. Wright PA. Fish Physiology: Nitrogen Excretion. Elsevier; 2001. 111-115 p.

51. Wade A. Maher B. Lawrence I. Davis N. Zoppou C. Bell C. Estimating the allowable ammonia concentrations in wastewater treatment plant discharge to ensure protection of aquatic biota. Environ Technol (United Kingdom). 1998;19(7):749-54.

52. James Stuart Schepers WR. Nitrogen in Agricultural Systems. James Stuart Schepers WR, editor. ASA-CSSA-SSSA; 2008. 186 p.

53. Environnement. Canada. Priority substances list assessment re- port. 1999;

54. Environment Canada H canada. Ammonia in the Aquatic Environment. Environment Canada; 2000. 103 p.

55. Jurčíková J. Mikula P. Dobšíková R. Némethová D. Svobodová Z. Effects of metazachlor on vitellogenin induction in Zebrafish (Danio rerio). Acta Vet Brno. 2007;76(SUPPL. 8):61-6.

56. Q. Ashton Acton. Endocrine Cells-Advances in Research and Application. Atlanta, Georgia, United States: ScholarlyEditions; 2013. $40 \mathrm{p}$.

57. Cavas T. In vivo genotoxicity evaluation of atrazine and atrazine-based herbicide on fish Carassius auratus using the micronucleus test and the comet assay. Food Chem Toxicol. 2011;49(6):1431-5.

58. Safety Information Atrazine. Sigma-Aldrich;

59. Safety Information Metazachlor. Sigma-Aldrich;

60. Milov M. Popadin A. On rainwater usage in Ashdod. Cent Ecol Syst Technol. 2009;54.

61. Carpenter SR. Caraco NF. Correll DL. W.Howarth R. Sharpley AN. Smith VH. Nonpoint pollution of surface waters with phosphorus and nitrogen. Ecol Appl. 1998;8(1998):559-68.

62. Sharpley A. Wang X. Managing agricultural phosphorus for water quality: Lessons from the USA and China. J Environ Sci (China). 2014;26(9):1770-82.

63. Perkins DL. Kann J. Scoppettone GG. The Role of Poor Water Quality and Fish Kills in the Decline of Endangered Lost River and Shortnose Suckers in Upper Klamath Lake. 2000;(September).

64. Alrumman SA. El-kott AF. Keshk SMAS. Water Pollution : Source \& Treatment. Am J Environ Eng. 2016;6(3):88-98.

65. Hunter PR. Waite M. Ronchi E. Drinking Water and Infectious Disease. Boca Raton, Florida, United States: CRC Press; 2002. 160 p.

66. Lehtola MJ. Laxander M. Miettinen IT. Hirvonen A. Vartiainen T. Martikainen PJ. The effects of changing water flow velocity on the formation of biofilms and water quality in pilot distribution system consisting of copper or polyethylene pipes. Water Res. 2006;40(11):2151-60.

67. Faust M. Altenburger R. Backhaus T. Blanck H. Boedeker W. Gramatica P. et al. Predicting the joint algal toxicity of multi-component s-triazine mixtures at low-effect concentrations of individual toxicants. Aquat Toxicol. 2001;56(1):13-32.

68. Sumpter JP. Johnson AC. Williams RJ. Kortenkamp A. Scholze M. Modeling Effects of Mixtures of Endocrine Disrupting Chemicals at the River Catchment Scale. Environ Sci Technol. 2006;40(17):5478-89.

69. Winson MK. Swift S. Fish L. Throup JP. JÃ rgensen F. Chhabra SR. et al. Construction and analysis of luxCDABE -based plasmid sensors for investigating $\mathrm{N}$-acyl homoserine lactone-mediated quorum sensing. FEMS Microbiol Lett. 1998;163(2):185-92.

70. Van Dyk TK. Majarian WR. Konstantinov KB. Young RM. Dhurjati PS. LaRossa $R$ a. Rapid and sensitive pollutant detection by induction of heat shock gene-bioluminescence gene fusions. Appl Environ Microbiol. 1994;60(5):1414-20.

71. Dohner E. Abby M. Barbour M. Simpson J. Byrne J. Dates G. et al. Volunteer Stream Monitoring : A Methods Manual. Environ Prot. 1997;1-227.

72. Grady C. P. Leslie. Lim Henry C. Biological wastewater treatment : theory and applications / C. P. Leslie Grady, Jr., and Henry C. Lim. M. Dekker New York; 1980. xiv, 963 :

73. The Lachish River: a high concentration of dangerous substances. Nrg Maariv [Internet]. 2009; Available from: http://www.nrg.co.il/ online/1/ART1/846/439.html

74. Eltzov E. Marks RS. Voost S. Wullings BA. Heringa MB. Flow-through real time bacterial biosensor for toxic compounds in water. Sensors Actuators, B Chem. 2009;142(1):11-8. 